\title{
O CURSO DE PARTOS: DEVE OU NÃO HAVER PARTEIRAS?
}

\author{
MARIALÚCIAMOTT \\ Doutora em História e pós-doutoranda na Escola de Enfermagem da USP
}

\section{RESUMO}

Este artigo analisa os cursos para formação de parteiras no Brasil, no século XIX. A documentação pesquisada é extremamente rica e levanta importantes questóes referentes à formação das parteiras, ao perfil de alunas desejado, à freqüência e ao número de alunas matriculadas, ao papel de médicos e parteiras no atendimento ao parto, à disputa profissional, como ainda, às relações de gênero e raciais, no período.

PARTEIRAS - FORMAÇÃO PROFISSIONAL - RELAÇÕES DE GÊNERO E RACIAIS - HISTÓRIA DA EDUCAÇÃO

\section{ABSTRACT}

TRAINING FOR MIDWIVES: SHOULD THERE BE MIDWIVES OR NOT? This articles analyzes the training courses for midwives in Brazil in the $19^{\text {th }}$ century. The documentation studied is extremely rich and raises important issues referring to midwives' training; the characteristics of the desired student, the frequency and number of classes; the role of doctors and midwives in attending births; and the still present professional dispute over gender and race relations.

Este trabalho faz parte da tese de doutoramento em História na USP (1998). A autora também publicou Romance de Ana Durocher, pela Siciliano, em 1995. Atualmente desenvolve a pesquisa em nível de pós-doutorado Caminhos cruzados: os cursos para formação de parteiras e enfermeiras em São Paulo ( /890-197/)junto ao Departamento de Enfermagem Materno-Infantil e Psiquiátrica e ao Centro Histórico-Cultural de Enfermagem Ibero-Americana da Escola de Enfermagem da USP. 
No Brasil, o reconhecimento da necessidade de se instruir as parteiras por meio de um curso regular sob orientação de um profissional do sexo masculino (médico-cirurgião), data da segunda década do século XIX. Joaquim Cândido Soares de Meireles, ao criticar o projeto de reforma das academias médico-cirúrgicas, elaborado pelo médico e deputado Lino Coutinho, em 1827, ressalta a importância da formação de parteiras, sobretudo num país novo, devido à necessidade de se incrementar a população. A falta de parteiras hábeis fazia, segundo o médico, que mulheres sem qualquer treino se tornassem parteiras, o que era desastroso, dada a alta taxa de mortalidade dos recém-nascidos (Meireles, 1828).

Nos diferentes projetos de reforma das academias médico-cirúrgicas elaborados pela Sociedade de Medicina identifica-se uma preocupação com a formação de parteiras e a lei de 3/10/1832, que criou as Faculdades de Medicina do Rio de Janeiro e da Bahia, determinou a criação do curso de Medicina e de Farmácia, exclusivos para o sexo masculino, e o de partos, para as mulheres que desejassem obter a formação e o diploma de parteira.

Nesse período houve ainda uma iniciativa particular. Em janeiro de 1832, o prussiano Le Masson apresentou um projeto sobre a necessidade de criação de uma maternidade no Rio de Janeiro onde seria estabelecido um curso de parteiras. Com o curso, justifica-se o pretendente, o governo do Brasil acabaria "com as manobras bárbaras e rodeadas de atos de fraude e de superstição praticadas pela ignorância em todas as províncias, até mesmo no centro da metrópole do Império", que destruíam a população à proporção que nascia. Para o cirurgião a arte de partejar era considerada de alta importância, pois "do conhecimento da vontade da natureza e das regras da arte aplicada à primeira época de vida (...) depende a conformação e a saúde futura do homem". Para tanto propunha estabelecer, na Corte, um hospital onde seriam admitidas apenas mulheres para parir e onde ele ensinaria mulheres a partejar (AN, cod.807, v.4).

No início da década de 40, a criação de cursos de parteiras foi discutida em âmbito provincial. No Recife, a criação de um curso público foi justificada pela Assembléia Legislativa de Pernambuco pela constatação de que não havia uma só parteira instruída na província; devido à recusa das parturientes a serem atendidas por médicos; e terceiro pelo fato de nenhuma pernambucana ter freqüentado, até aquele momento, os cursos de parteiras do Rio de Janeiro e da Bahia (AGCRJ, cód. 8-3-7).

assunto foi também objeto de preocupação das parteiras. Em 1832, a francesa Mme. Berthou', radicada no Rio de Janeiro, apresentou um memorial para a Assembléia Legislativa com o objetivo de instruir os parlamentares no momento da reforma do ensino

I. O documento tem por título Memorial para se consultar quando se tratar de uma nova organização das Escolas Médicas, oferecido à sábia consideração da Augusta e Digníssima Assembléia Legislativa por Mme. Berthout parteira mestre da Santa Casa de Misericórdia em 27 do julho próximo passado e enviado pela Comissão de Saúde Pública(Brenes, 1996, p.235-36). Mme. Berthou (Stephanie Marie Françoises Wernault) nasceu em I I/5/I 806, em Beauvois (França); formou-se pela Faculdade de Medicina de Paris, foi parteira da Santa Casa de Misericórdia do Rio de Janeiro, autora de uma manual de instrução de parteiras ( 1830 ) e exerceu a profissão por mais de 30 anos no Rio de Janeiro (Mott, 1998, p.54). 
médico, no qual preconizava entre outras medidas, a criação de uma Escola Nacional de Obstetrícia, para promover o aumento da população no Brasil. $\bigcirc$ curso de parteiras seria teórico e prático, com a duração de dois anos e regime de internato. As alunas deveriam ser jovens e recrutadas entre as recolhidas da Santa Casa de Misericórdia (Brenes, 1996, p.235 e 254-5).

Mme. Durocher, primeira parteira formada no Curso de Partos no Brasil2, em I87।, ao ingressar na Imperial Academia de Medicina, apresentou o trabalho "Deve ou não haver parteiras?" no qual faz a defesa do exercício profissional das parteiras, exigindo uma melhor formação para suas colegas de profissão. Defende um curso mais demorado, o que resultaria, certamente em um número menor de parteiras, porém seriam mais confiáveis, estariam mais bem preparadas e poderiam prestar relevantes serviços à sociedade, inclusive contribuindo "para destruir o preconceito contra médicos, preconceitos sustentados por estas comadres ignorantes e parteiras charlatãs" (1871, p.293). Mme. Durocher destaca uma outra razão para se fornecer melhor instrução às parteiras: acreditava que haveria maior respeito e consideração pela profissão, o que "dará o pão a muitas viúvas de médicos, de farmacêuticos e outras que não se matriculam, para não serem confundidas com aquelas que até hoje têmse matriculado, com honrosa excepção à parte" ( 87 I , p.294).

Apesar das diferentes razões apontadas para se instruir as parteiras, concretamente muito pouco foi feito. $\bigcirc$ reconhecimento da necessidade de instrução das parteiras por um ensino regular parece não ter sido uma questão indiscutível na sociedade brasileira no decorrer do século XIX. Se os projetos de criação de curso de parteiras revelam a preocupação com o assunto, a restrição ao funcionamento a apenas duas escolas em todo o Império, as exigências para ingresso, a falta de ensino prático, a demora em criar-se maternidadeescola, mais a falta de uma fiscalização efetiva para proibir o exercício da profissão a quem não tivesse diploma, parecem dizer que essa preocupação foi muito restrita.

Até mesmo a Imperial Academia de Medicina deu pouca atenção ao tema. Na sessão de 14 de agosto de 187।, Mme. Durocher fez a leitura de uma proposta, pedindo que se promovesse a criação de um curso de parteiras mais regular e melhor que o existente, bem como uma fiscalização mais efetiva do exercício profissional (Academia Imperial de Medicina, 1872, p.289). Foi criada uma comissão, que ao terminar os trabalhos concluiu que "apesar de toda a consideração que deve ser tida, não encerra em si um objeto que seja propriamente da alçada da Academia; pelo que deve ser arquivada como um documento precioso, para mostrar no futuro os bons desejos que tinha a Academia em ver a classe médica cercada de prestígio e venerada por ilustração" (idem, p.334).

2. Maria Josefina Matildes Durocher nasceu em Paris em 1809, veio para o Brasil em 1816 com a mãe, que abriu no Rio de Janeiro uma loja de tecidos e de moda. Formou-se parteira em I833, exerceu a profissão por cerca de 60 anos, tendo atendido mais de 5 mil partos. Publicou vários trabalhos na área de Obstetrícia e foi a primeira mulher admitida na Imperial Academia de Medicina (Mott, 1998). 
Este artigo refere-se basicamente ao ensino profissional para parteiras e, em particular, ao Curso de Partos da Faculdade de Medicina do Rio de Janeiro, ao de Le Masson, e ao de Recife. Gostaria de ressaltar que a documentação encontrada - os projetos de criação e reforma, a legislação e as críticas aos cursos, dentre outras - é extremamente rica e levanta questões referentes não apenas à formação das parteiras, ao perfil desejado das alunas, às disputas pelo campo profissional entre médicos e parteiras, como ainda às relações sociais e raciais no período. Ao mesmo tempo que os cursos excluíam as mulheres escravizadas, era principalmente sobre o corpo dessas mulheres (das parturientes escravas, negras livres e pobres) que as alunas do curso de parteiras e os alunos de Medicina adquiriram a sua prática.

\section{CRIAÇÃO E FUNCIONAMENTO DOS CURSOS DE PARTOS OFICIAIS}

A lei de 3/10/I 832 que criou as Faculdades de Medicina do Rio de Janeiro e da Bahia estabeleceu a organização de um curso especial para formar parteiras, em que eram admitidas apenas alunas do sexo feminino. A idade mínima exigida era a de 16 anos, as candidatas deveriam saber ler e escrever corretamente em Português e apresentar um atestado de bons costumes passado pelo juiz de paz da freguesia onde moravam, o que aliás não era pedido para os alunos do curso de Medicina, nem para os de Farmácia. Deveriam pagar, como os demais 20 mil réis pela matrícula. Essas exigências sugerem que se esperava alunas jovens, sem experiência prática adquirida com parteiras tradicionais (obtendo, conseqüentemente, toda formação por ensinamentos médicos), alfabetizadas, de moralidade comprovada e com recursos para poder pagar a matrícula.

Como era o curso? A lei determinava que as aulas fossem ministradas em particular para as alunas, pelo mesmo professor do curso de Medicina, da cadeira de "Partos, moléstia de mulheres pejadas e paridas, e de meninos recém-nascidos," que na época, no Rio de Janeiro, era Francisco Júlio Xavier. Pode-se dizer que o curso era teórico, embora as alunas tivessem maneiras não institucionais de praticar, como assistir os partos das escravas em casas de conhecidos ${ }^{3}$.

O curso como vinha sendo feito deve ter sido visto como insuficiente, pois Joaquim Cândido Soares de Meireles, em 1847, elaborou um projeto de reforma das faculdades de Medicina, propondo entre outras medidas, um curso de parteiras de dois anos, consistindo o segundo na repetição do primeiro, com freqüência obrigatória à clínica de partos (Moacyr, 1936-38, p. 446-583).

Em I 854 o ensino médico passou por uma reforma e as modificações foram extensivas ao curso de parteiras. Em relação às exigências para a matrícula, a idade passou a ser 21 anos e não mais 16 anos, e a moralidade das alunas passou a ser avalizada pela família: as

3. Mme. Durocher afirma ter tido aulas particulares, de diversas disciplinas, para completar a formação obtida no curso de partos (1887, p.250-I). 
solteiras deveriam ter a autorização do pai "ou de quem suas vezes fizer", e as casadas, dos maridos. As candidatas deveriam saber ler e escrever corretamente o Português, tendo sido incluídos nos exames preparatórios, as quatro operações e o Francês, o que certamente restringiu o acesso de muitas mulheres. $\bigcirc$ curso, que passou a se chamar Obstetrício, previa que as alunas matriculadas freqüentariam por dois anos a mesma cadeira de "Partos, moléstia de mulheres pejadas e de meninos recém-nascidos" do quarto ano médico (Decreto n. 1387, 28/4// 854) ${ }^{4}$. Deveriam também fazer os exercícios na respectiva clínica da Santa Casa de Misericórdia, e numa enfermaria especial em uma casa de maternidade que o governo criaria, quando fosse possível, o que aliás, só ocorreu cerca de 25 anos depois ${ }^{5}$.

Mme. Durocher, no artigo "Deve ou não haver parteiras?" critica o curso no que se refere às exigências para admissão das candidatas, ao tipo de ensino, ao tempo de duração e ao protecionismo que favorecia a dispensa de exames e freqüência de algumas alunas ${ }^{6}$. Para ela, exigir apenas saber ler e escrever em Português e Francês e as quatro operações significava que as alunas entravam sem preparo e não estavam capacitadas para acompanhar o curso:

A mulher que acaba de largar a agulha, o ferro de engomar, a panela, a frigideira ou qualquer utensílio da vida doméstica, vai ouvir por espaço de dois anos o professor falar de partos, em termos para ela completamente desconhecidos, como cartilagens, tendões, sinóvia, membrana serosa, mucosa, parênquima, articulação úmero-cubital, fontanela bregmática, etc., etc., circulação útero-placentária, descrição de embriologia; não percebe nem pintada, mas que importa? O fim principal não é perceber, é decorar, e para isso basta ter a inteligência um grau acima da de um papagaio, para decorar mais ou menos bem o que ouviu por espaço de dois anos. (Durocher, I87।, p.292)

Quanto ao ensino, questionava: "Agora perguntamos às pessoas de boa fé, se isto é sistema de ensino; se o repetir duas vezes o compêndio às mulheres que não estão preparadas para compreendê-lo é ensinar partos?" (p.293).

Nas décadas seguintes duas discussões dividiram a classe médica: a que previa a formação de parteiras de segunda classe, de um modo mais rápido, como acontecia na França

4. Aqui fica uma dúvida que a documentação levantada até o momento impediu de responder: as alunas teriam aulas três vezes por semana como os alunos do quarto ano (uma hora de duração, das 10 às I I horas da manhã)? Sendo o mesmo curso, elas não estariam capacitadas para praticar todas as operações obstétricas?

5. A clínica de partos na Bahia foi criada pelo Barão de Itapoã, em I 876, e funcionava na enfermaria de mulheres na Santa Casa de Misericórdia, em Salvador. No Rio de Janeiro começou a funcionar em I 88I, na Casa de Saúde de Nossa Senhora da Ajuda.

6. A autorização para fazer exame com dispensa da freqüência das aulas pode ser verificada na legislação. Em I\%/9/I868, autorizou que Margarida Falconet fosse admitida ao exame de obstetrícia ficando dispensada da freqüência das aulas (Decreto n. I 582). Edler afirma que a partir dos estatutos de 1854 , e no decorrer dos 30 anos seguintes, as faculdades de Medicina perderam a autonomia, tendo sido subordinadas aos diferentes gabinetes do Império. Foram freqüentemente pressionadas a admitir alunos sem os preparatórios completos, forçando os professores a favorecer a aprovação dos alunos (1992, p.5I e 54). 
e a que era favorável a maiores exigências nos exames preparatórios e um curso mais longo, com um número maior de matérias.

Em março de 1862, o conselheiro Jobim7, diretor da Faculdade de Medicina do Rio de Janeiro, elaborou um projeto de reformulação do ensino médico, no qual previa a criação de cinco escolas secundárias (São Paulo, Rio Grande do Sul, Minas Gerais, Pernambuco e Maranhão) para a formação de profissionais de segunda classe "puramente práticos", com o objetivo de prover a falta de médicos, farmacêuticos e parteiras no interior do Brasil e combater o charlatanismo. Numa carta enviada ao Marquês de Olinda, Ministro do Império, no ano seguinte, explica que não lhe parecia nem justo nem razoável que num território tão extenso como o Brasil, houvesse apenas duas faculdades de Medicina, ficando as demais províncias privadas do benefício de uma instrução médica. Tal situação lhe parecia nociva, ainda mais que, em algumas capitais, havia hospitais bem montados, onde seria possível o ensino prático e a Farmácia. "Parece que somos condenados a oscilar de excesso em excesso", diz o diretor. Anteriormente, no período que a fiscalização da profissão estava a cargo do Protomedicato e da Fisicatura-Mor, aprovavam-se "cirurgiões aos centos". Quando eram examinados, mostravam algum saber, tornavam-se depois bons práticos e prestavam socorros às povoações remotas, chegando até a servir no Exército e na Armada. Com a criação das Faculdades do Rio de Janeiro e da Bahia, apenas as populações dessas duas cidades passaram a ter acesso aos cuidados médicos; no resto do Império, a morte campeava. Os enfermos ficavam ao abandono, sendo socorridos por charlatães, já que os poucos médicos que por lá apareciam eram, em geral, gananciosos, tanto que muitas pessoas preferiam morrer, a serem "esfoladas em vida pelas exigências exorbitantes e desumanas destes adeptos da arte de curar" (AN, cód.I E3 26).

Jobim relaciona as dificuldades enfrentadas pelos candidatos aos cursos médicos oficiais. Poucos podiam vir de suas províncias estudar Medicina no Rio de Janeiro ou na Bahia, devido às exigências dos exames preparatórios, à freqüência de seis anos - o que custaria cerca de 10 a 12 contos de réis, "dispêndio enorme para qualquer pai de família". Dificilmente aqueles que se formassem, depois de tantos sacrifícios, se sujeitariam a viver no interior.

No que diz respeito às parteiras, o projeto embora liberal no sentido de possibilitar a formação mais rápida - estabelecia que o curso deveria ter a duração de um ano, portanto um ano a menos que os cursos de parteiras das Faculdades de Medicina do Rio de Janeiro e da Bahia -, e de não fazer qualquer referência à exigência de pagamento das matrículas, o que abriria o leque social das candidatas, aumentava, porém, o número de matérias exigidas no preparatório, igualando-o ao pedido para os candidatos dos cursos de Medicina e Farmácia (Francês e Inglês, Aritmética, Álgebra e Geometria), o que contraditoriamente, acabaria excluindo um grande número de mulheres.

7. Jobim foi médico do Paço, senador do Império, diretor da Faculdade de Medicina entre I 854 e I 872. 
O projeto foi apresentado em 1863 para ser avaliado por uma comissão formada pela Faculdade de Medicina. No parecer, os membros negam a falta generalizada de médicos e de farmacêuticos (o documento não faz referência às parteiras), e a necessidade de suprir essa carência por meio de escolas secundárias para formação de profissionais de segunda classe, pois acreditavam que as duas faculdades existentes eram suficientes. Afirmam que a formação dada seria precária e alertam para a concorrência: em pouco tempo, poderia aparecer um número excessivo de profissionais e que ao invés de aniquilar o charlatanismo, poderia apenas substituí-lo. Se efetivamente verificada a necessidade de profissionais em determinadas localidades, propunha, dentre outras medidas, que se desse licença aos "curandeiros" (práticos) que já exerciam o ofício. Caso fosse inevitável a criação de escolas secundárias, a comissão propunha algumas emendas. No que diz respeito ao curso de parteiras exigia que além das matérias do ano fosse feito um exame prático (AN, cód. I E3).

Dr. Souza Costa, num artigo publicado na Gazeta Médica do Rio de Janeiro, assim avaliou o projeto:

É uma verdade incontestável que em muitos pontos do interior do Brasil, principalmente em algumas províncias mais remotas, não existe número suficiente de médicos e farmacêuticos para satisfazer as necessidades de saúde pública, dando lugar a achar-se parte da nossa população sujeita aos botes de charlatanismo, aos erros de ignorância ou ao mais completo abandono. Mas uma vez chegados ao conhecimento desta verdade, muito ainda nos resta para saber e remediarmos o mal conhecido. Temos nós porventura procurado saber a causa desse mal? Será ele devido à insuficiência de médicos no país ou antes às circunstâncias de localidade dependentes da pobreza, falta de civilização e da disseminação de nossos habitantes por uma vasta superfície do território, cortada por poucas e péssimas estradas? (I863, p.248)

Para o autor a formação de parteiras de segunda classe parecia completamente dispensável. Seu argumento deixa evidente o desejo de reservar a prática obstétrica para os médicos. Afirma que no interior das províncias:

... onde poderiam se estabelecer (as parteiras) (...) só seriam chamadas nos casos graves, casos estes em que geralmente são chamados médicos, que por pouco que saibam dessa especialidade, sempre sabem mais que essas parteiras sem educação prática e apenas conhecendo algumas regras de Obstetrícia. (Idem, p.259-60)

$\bigcirc$ projeto de criação de médicos, parteiras e farmacêuticos de segunda classe foi rejeitado pela Congregação da Faculdade de Medicina do Rio de Janeiro, por 19 votos contra 2, no dia 19 de novembro de 1863 (AN, cód.I E3 26; Abreu, I 863, p.7). A discussão, porém, continuou por algumas décadas ${ }^{8}$.

8. Ainda na década de 80 , o projeto de se formar parteiras de segunda classe foi acalentado por alguns políticos. Rui Barbosa, em 1882, apresentou à Câmara um parecer sobre a Reforma do Ensino Secundário e Superior proposto por Leôncio de Carvalho, em I879, em que, entre outras medidas, propõe a formação de parteiras, dentistas e farmacêuticos de primeira e segunda classe (Barbosa, 1942, p.213-4). 
Mme. Durocher era contra esse tipo de formação:

Não passaremos adiante sem censurar a prática de alguns países da Europa, tais como a Itália, Alemanha e outros onde formam-se parteiras em 3, 6, 9 meses, bem como tais escolas secundárias dos departamentos de França, escolas sem garantias, sem confiança e sem importância alguma. No nosso entender, o meio saber é mais prejudicial do que a ignorância inteira; assim somos levados a crer que ainda no estabelecimento dessas escolas secundárias das províncias e dos departamentos, sob o pretexto de pôr a inscrição ao alcance de todos (à la portée de tout le monde), se reconhece a malévola e bem dirigida influência da França para aniquilar a pouca confiança e limitadíssimo conceito que ainda gozavam as parteiras em algumas famílias. (1870, p.269-70)

Para a parteira apenas as faculdades de Medicina poderiam formar parteiras. A duração do curso deveria ser de três anos, e não de apenas dois e os exames preparatórios ampliados, com a inclusão de matérias tais como Gramática portuguesa e francesa, Aritmética, Geometria, Geografia, História. No primeiro ano seriam ensinadas noções de anatomia geral, a bacia, em particular, e noções de fisiologia; no segundo, higiene e noções de clínica terapêutica; e no terceiro, partos e moléstias do útero ( 87 |, p.30 |-2).

Na reforma do ensino médico de 1879, pode-se dizer que a proposta de parteiras de segunda classe foi derrotada. $\bigcirc$ curso obstetrício passou a ser denominado Obstetrícia e Ginecologia e pelo enunciado do decreto, verifica-se que seriam aceitas as inscrições de alunos do sexo masculino. Vale lembrar que foi a partir desta reforma que as mulheres passaram a ter acesso aos cursos superiores, inclusive de Medicina. Para a inscrição exigia-se que os candidatos tivessem sido aprovados nos preparatórios de Português, Francês, Aritmética, Álgebra e Geometria. Os alunos do sexo masculino deveriam ter idade entre 18 e 30 anos e para as mulheres limitava-se apenas à idade mínima de 18 anos (Brasil, 1879).

Moniz Sodré Aragão afırma que a implantação da reforma operou-se de modo diferente, pois não aconteceu de uma só vez, ocorrendo aos poucos, levando cerca de cinco anos para concluir, depois de uma série de decretos, avisos, regulamentos "em que disposições várias eram criadas, aumentadas, alteradas, revogadas e substituídas por outras, só completando-se com o Decreto n. 9.31।, de 25 de outubro de 1884", que deu novos estatutos às faculdades (1923, p.45).

Nesses novos estatutos caíram as exigências de limite de idade para os candidatos de quaisquer um dos cursos das faculdades Medicina e aumentaram as matérias exigidas nos exames preparatórios. Os candidatos para o curso de Obstetrícia e Ginecologia deveriam fazer exames preparatórios de Português, Francês, Aritmética, elementos de Física, Química e História Natural. No curso seriam ensinadas anatomia geral e dos órgãos geniturinários da mulher, fisiologia em geral e dos órgãos geniturinários da mulher, farmacologia e higiene das parturientes, obstetrícia, clínica obstétrica e ginecológica, o que significa que houve uma evidente preocupação com a melhor formação das parteiras, pois, além de se prever e criar 
condições para o ensino teórico e prático da parturição, incluiu-se também o ensino de anatomia geral, de ginecologia e do uso dos medicamentos (Brasil, 1884).

Um projeto abortado: o curso de parteiras de Le Masson

Conforme já foi dito, o projeto de Le Masson", de criar uma escola particular para formação de parteiras na Corte, não chegou a sair do papel. A documentação levantada, porém, informa que o cirurgião não desistiu de seus propósitos facilmente: o primeiro projeto, data de 1832, e o último documento encontrado, de 1845! Durante cerca de 12 anos, tentou convencer as autoridades brasileiras sobre a importância da sua maternidadeescola.

O plano enviado para o governo brasileiro era calcado no modelo francês de formação de parteiras ${ }^{10}$. Previa receber alunas de todas as províncias cujo número seria estabelecido pelos governos provinciais, proporcionalmente ao número de cidades e da população. As despesas de dois contos de réis, por dois anos, ficariam a cargo do governo provincial e seriam parcelados em oito vezes " . Estipulava que essa despesa não saísse dos cofres públicos, mas de uma lista de subscrições ou então fosse paga com gêneros do país a uma casa de comércio estabelecida no Rio de Janeiro, ficando esta obrigada a repassar ao cirurgião. $\bigcirc$ regime seria de internato. As alunas seriam alimentadas, vestidas e instruídas pelo professor e teriam contato com o exterior do hospital apenas com autorização do estabelecimento. Um padre viria aos domingos e feriados para celebrar a missa e sempre que "forem necessários os socorros da religião". O curso seria aberto praticamente a todas as mulheres moças - com exceção das escravas - já que não fazia qualquer outra exigência para a inscrição. Não precisariam nem mesmo ser alfabetizadas, pois, segundo o plano de instrução, além de aprenderem a partejar por meio de um ensino principalmente prático, "um mestre irá todos

9. Florencio Stanislao Le Masson fornece algumas informações sobre si: ex-lente de partos e medicina legal, membro da Sociedade Medical de Westminster e da Sociedade de Sábios da Silésia e várias outras sociedades científicas e literárias, ex-primeiro cirurgião da Fragata Capitania da Esquadra Brasileira, estacionada no Rio da Prata "onde fez importantes serviços à nação" (AGCRJ, cód. 44-2-27).

10. Essa minha observação baseia-se nas informações de Azevedo Americano e Mota Maia sobre o curso de parteiras, feitas quando de suas viagens à França. Segundo o primeiro, os prefeitos escolhiam um certo número de mulheres, entre 18 e 35 anos, enviava-as a Paris ou aos hospitais municipais. Deveriam residir na maternidade por um ano, onde aprenderiam teoria e prática de partos, a sangrar, a vacinar e botânica relacionada a mulheres pejadas. No final do curso passavam por um exame, perante o professor, a parteira-chefe, o cirurgião, o conselheiro-geral dos hospitais e da faculdade de Medicina. As aprovadas deveriam voltar para seus departamentos ou para onde o prefeito achasse necessário. A diferença entre as propostas de Le Masson e o curso na França é que lá exigiam-se das candidatas as primeiras letras, certidão de bons costumes e certidão de casamento para as casadas, ou atestado de óbito dos maridos, para as viúvas; o curso era de um ano; o ensino das matérias era feito por diferentes professores; não havia qualquer vínculo do ensino à religião (Americano, 1845, p.33; Maia, 1876, p. 121 . Ver também: Gélis, 1988, p. 109-218, Stock-Morton, 1996, p.64-7; Brenes, 1996, p.74-129).

1 1. Na época isso significava que o custo do curso de cada aluna, depois de dois anos, equivaleria ao preço de cerca de oito escravos, conforme dados colhidos de anúncio no Jornal do Comércio, de 1832. 
os dias ao estabelecimento para ensinar a ler, a escrever e a contar". O cirurgião enfatizava que, no estabelecimento, as alunas deveriam ficar entregues a uma atividade contínua e a

...um estímulo necessário para o desenvolvimento (...) saindo desta estúpida inatividade (a qual lhes parece que estão postas no mundo só para servir as urgências sensuais do homem) elas alcançarão o demasiado sentido de sua dignidade e serão procuradas por homens de bem, os quais não terão o pejo de se associar a elas.

No final de dois anos seriam realizados exames perante o Ministro do Império e uma comissão da Academia Médico-Cirúrgica e as alunas receberiam um livro sobre a arte de partejar, de autoria do professor (AN, cód. 807, vol.4).

Le Masson pedia que a Regência lhe fornecesse um local favorável, pelo período de dez anos. Estava instalado num "pequeno hospital para tratar de mulheres de parto e seus respectivos filhos", desde 1829, na Ponta do Caju, considerado, então, distante do centro da cidade do Rio de Janeiro (AGCRJ, cód. 44-4-27).

Logo depois desse primeiro pedido, Le Masson levou seu "pequeno hospital" para um "bem apropriado e espaçoso local", próprio para a finalidade que se propunha, situado na rua do Espírito Santo, n.40, um ponto mais central da cidade ${ }^{12}$, e continuou sua cruzada por auxílio junto às autoridades brasileiras. Numa carta de Lino Coutinho recomendando o projeto para a Câmara Municipal do Rio de Janeiro, datada de I I/7//832, encontra-se uma nova versão do projeto (1\%/6/1832), mais detalhada que a anterior (AGCRJ, cód. 47-I-48). A necessidade da instalação de um curso desse tipo passou a ser justificada - não apenas pela ignorância das parteiras brasileiras e diminuição da população devido aos óbitos maternoinfantil - mas também pelo fato de o curso da Academia Médico-Cirúrgica ser teórico e destinado tão-somente aos alunos e não às parteiras - que eram, em geral, as que assistiam aos partos ${ }^{13}$.

No novo projeto, Le Masson apela para o patrocínio da Regência, dos presidentes de Províncias, dos vereadores e presidentes das Câmaras Municipais e, em particular das mulheres de elite. Estabelece que no seu hospital seriam recebidas para parir mulheres livres e escravas, particularmente aquelas que fossem recomendadas pelas princesas da Casa Imperial e pelas senhoras mais distintas da Corte "debaixo de cuja proteção está posto o estabelecimento".

O tempo médio de curso continuava a ser de dois anos e a inscrição ainda estava proibida às escravas, recebendo apenas mulheres entre 14 e 21 anos de idade. Além de

12. No /ornal do Comércio de I I/5// 832 se lê: "onde tem um hospital no qual são admitidas só mulheres para parir e para este fim tem quartos separados para as pretas por preço cômodo. Este estabelecimento sendo destinado ao ensino de partejar tem parteiras formadas para assistir privadamente na casa do estabelecimento para as senhoras que querem". Le Masson seria uma espécie de "agente", mandando as parteiras formadas em sua escola atender partos a domićlio?

13. Como acima foi mencionado, nessa data ainda não tinha sido criado o curso de partos nas faculdades de Medicina do Império. A lei de criação é de I 832, mas começou a funcionar, em I 833. 
responsável pelos uniformes, pelas despesas com o ensino, o professor se encarregaria também dos cuidados com a saúde das alunas. $\bigcirc$ regime seria de internato. Estavam proibidos os contatos fora do estabelecimento e a presença de homens, com exceção dos maridos das casadas, que seriam recebidos num quarto particular, quando fossem buscar suas esposas. $\bigcirc$ autor explicita melhor o tipo de ensino que seria dado às alunas. Além de ler, escrever e contar, seriam também ministrados alguns ensinamentos sobre a composição e a preparação de remédios, utilizados no momento do parto ou em casos de acidente, já que algumas das parteiras talvez fossem exercer o ofício onde não seriam encontradas boticas. Ressalta que as alunas aprenderiam a vacinar para ajudar na extinção da bexiga (varíola). $\bigcirc$ cirurgião prometia que quando as alunas voltassem para as províncias, levariam o instrumento necessário à vacinação para fazê-lo todas as vezes que fosse preciso; "conhecendo, contudo, o meio de conservar [o pus vacínico], o que podem obter das crianças confiadas aos seus cuidados". O curso seria teórico e prático. No início as alunas assistiriam aos partos apenas como observadoras, depois como assistentes, sob a direção do cirurgião, a fim de conhecerem bem as manobras. $\bigcirc$ modo de curar as pacientes e as crianças seria ensinado à cabeceira das doentes pelo professor e por uma parteira. Aprenderiam, ainda, a fazer as operações específicas à parturição e a sangrar, para que pudessem "praticar esta operação, necessária e indispensável em muitos casos, antes ou no ato mesmo do parto". As alunas que demonstrassem maior aptidão seriam nomeadas parteiras; as instruídas seriam assistentes de serviço por um determinado tempo; e as demais fariam a repetição das manobras, no próprio estabelecimento. As alunas aprovadas nos exames receberiam um diploma e estariam habilitadas para atuar em todo o Império. Levariam consigo um livro sobre a arte de partejar, adaptado às parteiras, de autoria do professor, com os ensinamentos teóricos e práticos necessários ao ofício e sobre os cuidados com as mães e filhos "servindo-lhes a dita obra para conservarem sempre claras as idéias e as poderem comunicar sem alteração a outras pessoas".

Ao discriminar as atividades dentro do estabelecimento e o que seria ensinado, deparamos com o perfil de aluna que era esperado. Afirma o professor que seriam permitidos "exercícios decentes e conforme ao seu sexo, mais úteis ao descanso da imaginação". Diz, sem meias palavras, que as alunas seriam incumbidas da rouparia e demais serviços domésticos "cujo manejo é de absoluta necessidade a uma mulher que se destina a ser mãe de família". Aprenderiam, ao mesmo tempo, "aquela facilidade de trato e de polidez de maneiras que são necessárias a uma mulher, que suposto seja de baixa condição(os grifos são meus), ter pelo seu ofício, em ocasião que se achar em contato com as pessoas da mais alta hierarquia e na conjuntura em que a delicadeza de maneiras é o maior alívio para as pessoas que sofrem".

No fim do curso seria feito um exame sobre as lições ensinadas, perante uma comissão escolhida entre os lentes da Academia Médico-Cirúrgica. Le Masson comprometia-se a reenviar as alunas diplomadas para as suas províncias de origem, com todos os cuidados e cautelas. 
No início de 1833, Estevão Alves de Magalhães, em nome do presidente da Câmara e dos vereadores do Rio de Janeiro, visitou o hospital de Le Masson, sendo-lhe entregue o projeto, novamente com algumas modificações, destacando-se a primeira cláusula que, além das escravas, passou a excluir também "as pretas" (AGCRJ, cód. 47- I-49).

Em fevereiro do mesmo ano, Le Masson enviou uma carta ao vereador Estevão Alves de Magalhães (AGCRJ, cód. 47-1-49), completando alguns tópicos do projeto. No que se refere à quantia paga por aluna, o preço cai para 400 mil réis anuais. As roupas deveriam ser trazidas pelas candidatas ( 12 camisas, 12 pares de meia, 2 espartilhos, 6 saias brancas, 6 aventais de cor, 3 pares de sapatos) e os sobrevestidos seriam fornecidos pelo estabelecimento. $\bigcirc$ cirurgião incluiu na correspondência dois impressos para explicar como seriam admitidas as parturientes. O patrocínio das senhoras - ou seja, a soma dada à escola - corresponderia ao número de parturientes (forras ou escravas) que cada uma destas senhoras poderia indicar para ali serem atendidas, como se verifica nos documentos a seguir:

Carta de admissão no Hospital para Mulheres de Parto e ensino de parteiras Rua do Espírito Santo, n.40 - Rio de Janeiro

Eu abaixo assinado receberei e farei tratar no trabalho de parto e suas próximas conseqüências pelo espaço de 2 I dias, incluso o em que parir, a pessoa que no dito hospital da minha direção se apresentar com esta carta, quer seja livre, quer seja escrava, sendo por isso enviada pela............................... a qual senhora terá bondade de declarar nesta mesma carta se a doente que a conduz é livre ou escrava e os seus nomes para a maior identidade. Rio de Janeiro, em.

Estabelecimento filantrópico de baixo do patrocínio das senhoras mais distintas do Rio de Janeiro (ou) Hospital para o ensino de parto e parteiras R. do Espírito Santo, n.40 Inscrição de....... que tem recebido da Ilma....... por a qual soma eu entrego....... cartas, pelas quais me obrigo a aceitar e tratar no trabalho de parto e suas próximas conseqüências, durante 21 dias........ mulheres sejam escravas da mesma senhora ou sejam livres, cada doente com uma das cartas acima mencionadas, do número....... até........

Nesse adendo, informa que no hospital seriam seguidas as seguintes regras: "as doentes" - como se refere às parturientes - receberiam os caldos, comida, medicinas, banhos e tudo que fosse necessário "conforme o seu estado"; não poderiam receber comida ou bebida de fora do hospital, nem receber visitas, apenas aquelas mandadas "por ordem da sua benfeitora". Também, a benfeitora seria avisada da data da saída da recém-parida do estabelecimento. 
O projeto de Le Masson recebeu parecer favorável da Comissão de Instrução Pública e da Comissão de Saúde Pública da Câmara dos Deputados que reconheceram a importância e necessidade do estabelecimento ${ }^{14}$. Porém esbarrou naquele que deveria ser dado pela Faculdade de Medicina do Rio de Janeiro.

Francisco Júlio Xavier, professor de partos incumbido de dar o parecer, engavetou o projeto por cerca de 12 anos! Num artigo, publicado numa revista médica, justifica a demora: acreditava que esse seu silêncio fosse entendido pelo pretendente como uma negativa (1845, p.257-62). Apenas depois de se ver pressionado por várias vezes pelo próprio Le Masson e de receber um "Aviso", decidiu trazer a público suas críticas.

No parecer, Xavier reconhece a necessidade da criação de uma maternidade para atender a população pobre e miserável e para a instrução, pois a Santa Casa de Misericórdia, onde os estudantes deveriam praticar, não possuía as condições necessárias para atender parturientes nem os recém-nascidos. Mas alertava que a maternidade, diferentemente do proposto, deveria também ser usada para a prática dos alunos da Faculdade Medicina, não apenas para a das parteiras. O professor eximia-se de fazer uma avaliação da maternidade em si, pois, segundo informa, Le Masson não teria apresentado um plano geral de organização, o regimento da clínica de partos, a disposição, a divisão, a classificação e o número das enfermarias. No entanto, duvidava que o estabelecimento tivesse apenas finalidade filantrópica: além das alunas, as parturientes, mesmo as pobres, deveriam pagar dez mil réis "de sorte que além de sofrerem os exames, e de estarem durante o seu parto à vista de todos, quando dele tiram proveito para a instrução, devem ainda pagar dez mil réis!", exclama indignado $^{15}$.

Argumentava ainda que Le Masson, se fosse nomeado lente do curso por ele criado, e autorizado a dar diploma de parteira às alunas, estaria se colocando acima da autoridade da Faculdade de Medicina, única autorizada pelo governo a conferir diploma (Brasil, 1832). Para se conseguir isso seria necessário revogar a lei na parte relativa às parteiras, o que seria imprudente, já que iria animar a ignorância e excitar o charlatanismo. Sem ter conhecimento do indivíduo e de sua aptidão - dizia num tom visivelmente provocador - não deveria ser feito aquilo que pedia, pois existem "aventureiros que lançam mão, a tudo se arriscam para fazer fortuna(...). Não devemos acreditar em tudo que nos quer fazer crer". Xavier colocava em dúvida a pessoa, a competência e as intenções do cirurgião, afirmando que ele não tinha diploma reconhecido pela Faculdade - nem mesmo havia apresentado um diploma' ${ }^{16}$ - "que não sendo uma pessoa conhecida por sua ciência por suas obras, por seus trabalhos ou por

14. Essa documentação é mencionada por Xavier e certamente fazia parte do dossiê que tinha em mãos. Infelizmente não foi localizado (Xavier, 1845, p.258).

15. Informação retirada de uma carta de Le Masson ao Conselheiro Maia (Xavier, 1845, p.258).

16. Os médicos estrangeiros para exercerem no Brasil deveriam ter seus diplomas verificados pelas faculdades de medicina do país. 
outros quaisquer fatos não devemos jurar em suas palavras sobre negócio de tanta magnitude e de importância sabida" (Xavier, 1845, p.259-60). Menos que a prática de um ato benemérito, Xavier identificava razões pecuniárias nas intenções do cirurgião:

...porquanto se o governo não paga, pagam as parteiras, as pensionistas, e todas as mulheres que se destinam a arte de partejar. Quanto aos estudantes do sexo masculino, estão as suas portas fechadas, por que ele só pretende ensinar a prática que falha, e que quer fazer desaparecer, a mulheres, por isso vem o ensino a ficar incompleto. Considerado assim o Hospício de Maternidade, como quer o Sr. Le Masson, julgo que não merece o menor favor do governo, porque resultam mais vantagens em seu favor, do que proveito à instrução pública; ele exige mais do que deve. (Idem, p.260)

Propõe que fossem indeferidas as pretensões no que se refere ao exercício da Medicina e do ensino público.

Fernando Magalhães, ao analisar o parecer dado por Xavier, afirma que duas coisas deveriam ser ponderadas: a improcedência da idoneidade profissional, já que Le Masson exercera lugar técnico como cirurgião da Armada Brasileira, e o fato de a idéia não ter sido aproveitada por outra pessoa "com idoneidade, títulos, com direito e mesmo com a obrigação de executar" (Magalhães, 1922, p.226).

A meu ver, outras questões deveriam ser ponderadas. A primeira refere-se à autonomia da Faculdade de Medicina sobre as decisões na sua área, o monopólio do ensino médico (e obstétrico) e a exclusividade na concessão de diplomas. Vale ressaltar que a primeira versão do projeto de Le Masson era do início de 1832, quando ainda não havia um curso de parteiras no país. Depois da aprovação do projeto de criação das faculdades de Medicina, em outubro de 1832, o curso proposto não teria se tornado um concorrente ao curso oficial de parteiras?

A lei de criação das faculdades de Medicina, no artigo 33, previa o ensino livre, ou seja, qualquer pessoa, brasileira ou não poderia ensinar os diversos ramos da ciência médica, sem oposição alguma por parte da faculdade ${ }^{17}$. Porém apenas as faculdades de Medicina estavam autorizadas a conferir diplomas. Portanto, Le Masson estava autorizado a estabelecer seu curso. A questão jurídica, no que se refere a passar diplomas, não poderia ser ajustada com alguma recomendação de Xavier para modificação no projeto de Le Masson?

A demora do parecer, a menção à ilegalidade do curso e o respeito por parte do governo à opinião do professor podem ser sintomas da autonomia da Faculdade de Medicina no período, autonomia que será perdida depois da reforma de 1854.

Por outro lado, como o próprio Xavier ressalta, o curso de parteiras de Le Masson excluía os estudantes de Medicina da prática obstétrica, pois o hospital seria para a formação exclusiva das alunas. Maternidade-escola, sim! A necessidade ninguém questiona, a faculdade precisava de uma

17. Em Minas Gerais, por exemplo, funcionaram dois cursos de Farmácia. 
para seus alunos. Mas uma maternidade apenas para formação de parteiras, não! Será que nas entrelinhas da recusa do professor não haveria uma preocupação com a concorrência que parteiras mais experientes fariam aos médicos formados pela faculdade de Medicina?

Deve também ser mencionada a existência de uma visível competição profissional entre os profissionais nacionais e os estrangeiros, verificada desde o tempo da Fisicatura-Mor ( 1808 - | 828) entre os portugueses formados por Coimbra e aqueles formados pelas academias e escolas médico-cirúrgicas do país, depois entre os médicos nacionais diplomados no Rio e na Bahia e aqueles formados pelas diferentes faculdades de Medicina européias, que exerciam sua profissão no Brasil ${ }^{18}$.

Por último, não pode ser descartada a influência do parecer negativo de questões como: o tipo de aluna esperado no curso (mulheres provenientes das classes mais desfavorecidas da sociedade); a forma de admissão das alunas, no qual não estavam previstos exames preparatórios, admitindo-se alunas analfabetas; a formação profissional proposta, mais voltada para os conhecimentos práticos que para os teóricos. Será que o perfil das parteiras formadas no curso de Le Masson estaria em desacordo com o desejado pelos médicos?

\section{A AULA DE OBSTETRÍCIA DE RECIFE}

curso de parteiras ou, como era chamado, Aula de Obstetrícia, foi criado pela Lei Provincial de Pernambuco (Pernambuco, 1840): "com um professor para reger uma cadeira de Arte Obstétrica teórica e prática, compreendendo Anatomia, e Fisiologia respectiva, e moléstias provenientes de partos e que será freqüentada por mulheres". O curso foi dotado com um conto de réis ${ }^{19}$, sendo regulamentado pela Instrução do presidente de província (Pernambuco, |84I).

As aulas começaram em julho de 1840 e eram ministradas pelo médico Simplício Antonio Mavignier ${ }^{20}$. Com exceção da matrícula, que era gratuita e feita na casa do próprio professor e da inexistência de regras referentes ao limite mínimo de idade, as demais exigências eram semelhantes àquelas das faculdades de Medicina da Corte e da Bahia (Brasil, I 832): a candidata deveria saber ler e escrever corretamente, além de ser obrigada a apresentar um atestado de bom comportamento, passado pelo vigário ou pela autoridade policial da respectiva freguesia.

18. Vários incidentes acirraram essa disputa: declarações feitas por alguns médicos estrangeiros sobre o estado da arte no país, livros escritos por estrangeiros detratando médicos brasileiros, depois de viagens pelo Brasil, e a preferência pelos serviços prestados por médicos estrangeiros por muitos brasileiros e estrangeiros aqui residentes.

19. Era então presidente da Província Francisco Rego de Barros. A criação da cadeira acha-se no capítulo 7 da referida lei provincial, no tópico referente ao orçamento de Saúde Pública e Socorros e Beneficência, e não no de Instrução Pública. Apenas em 1842, a dotação da Cadeira de Obstetrícia passou a sair da verba destinada à Instrução Pública.

20. Simplício Antonio Mavignier ( 1800 - 1856) nasceu em Recife e estudou Medicina em Paris. Além de professor de obstetrícia foi professor de Física no Liceu Provincial, redator de várias revistas médicas e tido como um dos parteiros mais conhecidos do Recife no período (Costa, 1982). 
Cada ano letivo tinha a duração de dez meses (entre fevereiro e novembro), com aulas três vezes por semana, de duas horas cada. No currículo estava previsto o ensino de arte obstétrica teórica e prática, compreendendo anatomia, fisiologia e moléstias provenientes do parto. Apesar de sujeito à inspeção do diretor do Liceu Provincial, o curso estava estabelecido fora de suas instalações. Leduar de Assis Rocha afirma que as aulas eram ministradas no Hospital Paraíso. A freqüência era obrigatória e as alunas que tivessem I 5 faltas não justificadas ou 30 justificadas estavam proibidas de fazer o exame. Depois do primeiro ano, as alunas eram obrigadas - também como nos cursos de parteiras das faculdades de Medicina - a freqüentar um segundo ano para repetição das matérias. Só então poderiam prestar os exames, que eram vagos, presididos pelo professor de partos, feitos na presença do diretor do Liceu, de um delegado e dois facultativos especialmente convidados. A aluna aprovada e que tivesse bom comportamento, obteria o título de parteira, sendo obrigada a registrar o diploma na respectiva Câmara Municipal do local em que iria exercer a profissão (1953, p.27-133).

A Instrução de 30/3/I84I, além do curso, regulamentava o exercício da profissão. $\bigcirc$ artigo 2 I estabelecia que dois anos depois da abertura da aula nenhuma mulher poderia exercer a profissão de parteira na Província de Pernambuco sem ter título passado pela Cadeira de Obstetrícia ou por qualquer escola ou academia nacional legalmente autorizada; e o artigo 22 dizia que as Câmaras Municipais, em seus respectivos distritos, deveriam ter a maior vigilância e cuidado para que não exercessem a profissão de parteira mulheres sem título, passado da forma acima referida (Pernambuco, I 84I).

Numa avaliação da cadeira feita pelo professor Mavignier a Gonçalves Dias, que estava incumbido de fazer um relatório sobre a situação do ensino no Império, são mencionados os benefícios do curso: as parteiras estavam mais bem instruídas, mais prudentes e identificavam dificuldades e embaraços, além de pedirem a presença de um médico a tempo, "não confiando tanto em si, nem nos seus processos rotineiros". $\bigcirc$ professor menciona também algumas das dificuldades enfrentadas:

...aplicam-se a este ramo mulheres de classe inferior, e quando a idade poucos recursos thes oferece: daqui dois inconvenientes - em primeiro lugar carecem de quase todo o desenvolvimento intelectual; e depois a quadra da vida já não é mais própria para o estudo. Por fim são mulheres que vivem do seu trabalho - e essa não muito larga aplicação que podem ter é, a cada momento, interrompida pela necessidade de granjear o material da vida. (Almeida, 1989, p.35I)

Apesar de elogios e de reconhecimento do professor para com suas alunas, o curso sofreu uma progressiva diminuição da dotação ${ }^{21}$, recebeu algumas críticas e foi alvo de

21. “...todavia, no orçamento de 1843 , a dotação caíra para 800 mil réis, por volta de 1844 (...) fixou o governo o estipêndio de 600 mil réis, baixando-o para 500 mil réis, quantia que perdurou até os últimos dias da aula, cerca de I860" (Rocha, 1953,p. 129). 
denúncia por infringir a legislação geral. No relatório que o presidente de província Chichorro da Gama apresentou à Assembléia Legislativa de Pernambuco, em I 847, foram feitas algumas propostas de mudança: o curso não deveria estar vinculado ao Liceu, mas ao Conselho Geral de Salubridade, formado por profissionais da área médica; deveria haver o ensino prévio de outras matérias, como a anatomia e a fisiologia, antes da obstetrícia propriamente dita, pois, de outra forma, as alunas poderiam "cometer erros grosseiros, que comprometem a vida de muitas pessoas" (1847, p. 10).

O desprezo pelo curso pode ser verificado no tom das observações feitas pelo vigário Venâncio H. de Rezende, diretor-geral interino de Instrução Pública: "a Cadeira de Obstetrícia é como uma orelha-de-pau [um fungo, corpo estranho] neste estabelecimento (Liceu Provincial): teve ela umas 12 alunas no corrente ano, destas saíram algumas aprovadas, outras não, algumas perderam o ano e tencionam continuar no ano corrente" (Figueiredo, I855, p.2).

A questão jurídica já havia sido levantada por Gonçalves Dias em seu relatório, em 1 852, ao ressaltar que a Escola de Obstetrícia não the parecia conforme a lei da criação das faculdades de Medicina de 1832. Porém, o assunto só teve uma repercussão mais ampla a partir de uma consulta feita em 1854, pelo presidente da Comissão de Higiene Pública de Pernambuco, à Junta Central de Higiene. O representante de Pernambuco comunicava ao órgão central a existência da referida aula, alertando, inclusive, que o curso estava dando diplomas e autorizando o exercício da profissão a mulheres que não tinham a instrução necessária. Perguntava se as parteiras diplomadas poderiam "ser admitidas à matrícula do Artigo 28 do Regulamento de 29/9/I85। a despeito da lei de outubro de I832" (AGCR), cód.8-3-7) 22 .

Talvez não seja demais lembrar, conforme antes referido, que a lei de outubro de I 832 estabelecia que sem título conferido ou aprovado pelas duas faculdades de Medicina do Império ninguém poderia curar, ter botica ou partejar; e o Decreto de 29 de setembro, regulamentava as atribuições da Junta de Higiene Pública, no que diz respeito ao exercício profissional de médicos, cirurgiões, boticários e parteiras. Só poderiam exercer a profissão aqueles que tivessem freqüentado e sido aprovado na Faculdade de Medicina do Rio de Janeiro ou a da Bahia, ou nelas tivessem verificados os títulos obtidos no estrangeiro, e registrados seus diplomas nas respectivas juntas provinciais.

O representante de Pernambuco e o presidente da Junta Central tiveram o mesmo parecer: as alunas do curso de Pernambuco não poderiam registrar seus diplomas na junta, acrescentando ainda que "as resoluções das Assembléias Provinciais não poderiam ter vigor de uma lei geral”. Antes de tomar qualquer decisão, o presidente da Junta Central levou a questão ao Governo Imperial, o que resultou numa série de consultas e discussões. $\bigcirc$ imperador ordenou que o presidente da província o informasse sobre a matéria. José Bento

22. Todas as informações a seguir sobre o curso de parteiras foram retiradas do documento citado. 
da Cunha Figueiredo, como resposta, reiterou a utilidade pública da cadeira, bem como a necessidade da sua manutenção. Incluiu um ofício do professor Mavignier, historiando a criação da Aula de Obstetrícia. $O$ documento é precioso. Segundo o professor, a aula tinha sido criada a partir das discussões ocorridas na Assembléia Legislativa de Pernambuco. Tomando-se em consideração as condições do país, chegou-se à conclusão que não havia uma só parteira, na região, que tivesse "a menor instrução, e uma prática um pouco esclarecida". As mulheres em Pernambuco, "como por toda parte", dizia, queriam ser atendidas, em seus partos, por mulheres, e não por facultativos de Medicina, admitindo médicos ou cirurgiões apenas em casos extremos de grande perigo. Argumentou-se, ainda, no legislativo, que nenhuma mulher da província, até aquele momento, tinha freqüentado o curso de parteiras nas Faculdades de Medicina do Rio de Janeiro e da Bahia e "não havia esperança que parteiras hábeis", formadas naquelas escolas, se estabelecessem em Pernambuco. Ao expor as exigências para a matrícula e o currículo, o professor ressalta que o curso era teórico e prático, e para demonstração havia bacias de mulher de conformação normal e viciada, uma "grande coleção de estampas", dois manequins e uma coleção de fetos de diferentes idades. Quanto ao ensino prático, ele próprio levava as alunas para verem e praticarem quando era chamado para fazer algum parto, "especialmente das mulheres pobres e desvalidas". Fazendo um balanço do curso, Mavignier afirma que desde a criação tinham sido feitas 116 matrículas (entre 1840 e 1854). O número de alunas matriculadas havia crescido gradualmente: quando abriu tinha 5, em I85 I, em I852, I I, e em 1853, 12 alunas, sendo seis para o primeiro e seis para o segundo ano. Das 32 alunas que examinou, só uma tinha sido aprovada simplesmente, todas as outras, plenamente, duas dentre elas com distinção, "dada espontaneamente pelos examinadores, porque elas haviam satisfeito mais do que era necessário para sua aprovação plena". Quanto à qualidade da formação oferecida às alunas, defende que esta poderia ser verificada pelo fato de as parteiras aí diplomadas serem as preferidas, inclusive pelos médicos, que utilizavam os serviços "para assistirem as respectivas consortes na ocasião do parto e não consta que tenham tido razão de queixa". Se o curso não tinha formado nenhuma parteira "insigne", justifica-se o professor, devia-se ao fato de que as mulheres que tinham meio de subsistência não queriam ser parteiras, e as outras não podiam estudar no Rio de Janeiro e na Bahia. "Hoje já freqüentam o curso mulheres muito moças e de talentos, estas virão a ser muito peritas, estudando". E conclui com a seguinte frase: "O Rio de Janeiro não faz exceção, pois as parteiras que lá existem são estrangeiras, nacionais não há uma que tenha estudado na Academia de Medicina"23.

Francisco Gomes Campos, procurador da Coroa, Soberania e Fazenda, foi consultado e ao analisar a questão afirmou que a Aula de Obstetrícia era:

...uma instituiçãa providente e benéfica que honra os seus autores e a Lei Provincial que a criou pois, em sua letra não afeta as disposições das leis gerais sobre a polícia sanitária,

23. Todas as informações a seguir sobre o curso de parteiras foram retiradas do documento citado. 
porém o regulamento dado pelo presidente da Província ${ }^{24}$ em verdade ampliou-a consideravelmente, e contém artigos que parecem, mas que por direito não podem, prejudicar aquelas disposições, como ponderara o presidente da Junta de Higiene em sua informação. (NA, cx.IS4-23, doc. 72)

O procurador conclui: "conformo-me portanto com o seu parecer [do presidente da junta] e entendo que sem embargo do referido Regulamento Provincial, deve a comissão desempenhar os seus deveres, fazendo por em fiel observância as determinações do seu instituto" (idem, ibidem). A discussão jurídica continuou, indo para a Seção dos Negócios do Império do Conselho do Estado. Para os conselheiros a criação do curso e a regulamentação do exercício da profissão por lei provincial não deveriam prejudicar as leis gerais sobre a Polícia Sanitária. Também contrariava a Lei Orgânica das Escolas e Faculdades de Medicina do Império (Brasil, I 832) e não poderiam habilitar para a matrícula na junta, conforme o Artigo 28 do Regulamento de 28 de setembro de 185 I. Portanto, concordavam com os pareceres anteriores. Porém, depois de dar a opinião, os conselheiros fazem uma ressalva:

.... Seção pede a vênia de Vossa Majestade Imperial para ponderar que seria duro e até contrário à utilidade pública qualquer procedimento que importasse perseguição das alunas de que se trata. Elas não possuem plena instrução na arte de partejar, acham-se todavia mais habilitadas do que essas mulheres que por toda a parte, sem excetuar esta cidade do Rio de Janeiro, onde há uma Escola de Medicina, são chamadas por falta de parteiras, nos casos ocorrentes. Será pois no sentir da Seção, conforme os princípios de eqüidade e ao império, da necessidade de não se perturbar no exercício de sua arte as parteiras que tiverem obtido títulos passados na forma que prescreve o Regulamento feito pelo Presidente de Pernambuco em execução da Lei Provincial, que criou a Cadeira de Obstetrícia, arte que se haja de regular este objeto de modo geral. O Governo Imperial já fez aplicações desses princípios, modificando o rigor do Regulamento de 29 de Setembro de I85।, em favor dos Boticários que estivessem nas condições expressadas nos pareceres da Seção de I 5 de Janeiro, e de 24 de Maio de 1853. O ato da Assembléia Provincial Pernambucana vem mais firmar a Seção na opinião, que tem tido a honra de manifestar em pareceres anteriores, acerca da necessidade de se facilitarem os estudos médicos, e habilitarem para o exercício da Medicina pessoas que não podem freqüentar as Academias. Vossa Majestade Imperial em Sua Sabedoria resolverá o melhor. (AN, caixa I S4 23, doc. n.49 e caixa I S423, doc. 72)

O parecer foi assinado por Cândido José de Araújo Viana, pelo Visconde de Monte Alegre e pelo Visconde de Olinda.

24. Todas as informações a seguir sobre o curso de parteiras foram retiradas do documento citado. Como já foi dito, a lei de 1832 que criou as faculdades de medicina possibilitou a existência de cursos livres, que estavam, porém, impedidos de dar diplomas. Na Instrução de março de 1841, o presidente de província autoriza o reconhecimento de diplomas das alunas do curso de Pernambuco (AN, cx. IS4-23, doc. 72). 
Por intermédio de uma carta confidencial do Ministro de Estado dos Negócios de Império, ao presidente da Província de Pernambuco, fica-se sabendo o que foi resolvido: as alunas da Cadeira de Obstetrícia não deveriam ser matriculadas na junta, porém poderiam continuar a exercer o ofício sem serem perturbadas!

Dois anos depois, uma das alunas do curso, Isabel Maria Rodrigues, pediu autorização para ser admitida no exame de suficiência em obstetrícia, na Faculdade de Medicina do Rio de Janeiro, alegando que tinha diploma, conferido pelo presidente da Província de Pernambuco. O Aviso n. 160, de 4 de abril de 1861, do Ministro dos Negócios do Império, publicado na Coleção de Leis e Decisões do Império, informa, ao diretor da Faculdade de Medicina, que as parteiras formadas por aquela escola não estavam em situação de igualdade àquelas diplomadas pelas escolas estrangeiras, sendo assim negado o direito de fazer o exame (Brasil, |86|).

Segundo Leduar da Rocha, depois da morte do professor Mavignier, em 1856, o curso entrou em franco declínio, até que o governo se desinteressou e o extinguiu (1953, p. | 33).

Não consegui precisar a data final do curso. $O$ Liceu Provincial, ao qual estava vinculada a Aula de Obstetrícia, foi extinto, ou melhor, transformado no Ginásio Provincial, pelo Regulamento Provincial de 27 de julho de 1855 (Pernambuco, 1855), sendo aí admitidos apenas alunos do sexo masculino, que estudavam em regime de internato. Mesmo o curso de parteiras se constituindo numa "orelha de pau" do liceu e funcionando num hospital, é possível que tenha sido extinto juntamente com o liceu, principalmente depois das denúncias acima mencionadas, levadas ao conhecimento da Junta Central de Higiene.

Em 1875, foi reaberto um curso de Partos em Recife, no Hospital Pedro II, em vista da disposição do artigo 47 do Regulamento de 29 de abril de 1875 "o médico diretor dará duas vezes por semana, em uma das horas da estada em seu hospital, lição de obstetrícia às mulheres que quiserem ter prática de trabalho natural de parto" (Pernambuco, 1875).

Em 1875 o curso estava sob a direção de Dr. João Pedro Maduro da Fonseca, e foi freqüentado por três alunas (Morais, I876, p.42-3); em 1876, foi freqüentado por seis alunas, das quais três prestaram exames e obtiveram atestado de aproveitamento (Cunha, 1877 , p.43); em 1877, três freqüentaram e apenas uma foi examinada e aprovada (Lacerda, 1879 , p. 16). Primitivo Moacyr informa que em 1884 "a Aula de Obstetrícia funcionou regularmente no Hospital Pedro II, a cargo do Dr. J.P. Maduro da Fonseca, diretor do Serviço Sanitário da Santa Casa de Misericórdia, tendo habilitado duas alunas" (1936-38, p.556).

\section{A FREQÜÊNCIA DOS CURSOS: UMA QUESTÃO INTRINCADA}

A partir das Memórias Históricas da Faculdade de Medicina do Rio de Janeiro foi possível fazer um levantamento da freqüência das alunas no curso de parteiras da Faculdade de Medicina do Rio de Janeiro: uma aluna em I 834, uma em I838, uma em I 839, uma em I853, uma em 1857, duas em 1868, duas em 1869, duas em 1870, uma em I875, uma em 1876. Pela 
localização do livro de matrículas, Dilce Rizzo Jorge somou 2 I alunas, para o Rio de Janeiro, no período entre 1832-1901; e três, para o mesmo período, na Bahia (1972, p.53).

O número de alunas matriculadas e formadas pelo curso sempre foi, no período, muito pequeno ${ }^{25}$. Tanto em relação à população do Rio de Janeiro e da Bahia, onde funcionavam as escolas, como em relação à população do Brasil, se lembrarmos que eram os únicos cursos autorizados a fornecer diploma de parteira e, portanto, deveriam receber alunas de todo o Império.

A freqüência no curso de Recife foi maior. Os relatórios dos presidentes da Província atestam que em I 849 teve sete alunas; em I 85 I , I I alunas, seis no primeiro ano e cinco no segundo, sendo que habilitaram-se quatro; no ano de 1854, também II alunas, sendo quatro aprovadas. Em 14 anos, segundo o professor Mavignier, conforme mencionado, formaram-se 32 alunas.

Apesar dos projetos de criação e de reforma, as críticas e a legislação sobre os cursos de partos no Brasil, entre 1827 e 1884, apontarem para o reconhecimento da necessidade da formação de parteiras, não foi encontrada uma palavra sequer sobre a maneira como essas alunas deveriam ser recrutadas ou algum tipo de propaganda convocando alunas ${ }^{26}$, nem uma análise sobre a freqüência dos cursos. Pode-se dizer que na documentação levantada, o reduzido número de alunas matriculadas nos cursos de partos foi lembrado apenas pela Assembléia Legislativa de Pernambuco, quando das discussões sobre a criação de uma Aula de Obstetrícia, para mulheres, naquela província.

O texto de Mme. Durocher, "Deve ou não haver parteiras?", é um bom exemplo neste sentido (|87|, p.30|). Mesmo fazendo uma eloqüente defesa da necessidade de haver parteiras, a solução apregoada diz respeito a maiores exigências nos exames preparatórios, a uma formação mais demorada, com um número maior de matérias, e, não, a um questionamento da razão de o curso, mesmo sem o rigor desejado, não ter alunas.

Dilce Rizzo Jorge atribui a ausência de alunas ao regime patriarcal, no qual a mulher vivia reclusa, tinha restringida a convivência com os homens, casando-se precocemente. Apenas moças de boa família recebiam uma boa educação e estariam capacitadas para as exigências dos exames preparatórios. Argumenta que a essas moças dificilmente seria permitido freqüentar um curso juntamente com os alunos do sexo masculino, ou exercer uma profissão que vinha sendo exercida há anos "por curiosas da mais baixa classe socioeconômica" (1972, p.59).

Concordo com Dilce Rizzo Jorge quando considera a profissão de parteiras desvalorizada, que as mulheres educadas que poderiam fazer os exames preparatórios dificilmente

25. É brutal a disparidade entre o número de alunas formadas pela Escola de Parteiras de Paris e as formadas, seja nos Cursos de Partos da Faculdade de Medicina do Rio de Janeiro, como no da Bahia: em 75 anos ( 1802 e 1877) lá se inscreveram 5.445 alunas, sendo que 4.413 completaram o curso (Brenes, 1999, p. 43).

26. A propaganda anunciando o curso de parteiras, por meio de cartazes e cartas circulares era feita na França no século XVIII (Gélis, 1988, p. 136-8). 
fariam essa opção profissional e que as mulheres das camadas mais abastadas tinham algumas restrições em conviver com os homens, por exemplo, em salas de aulas.

Não se pode esquecer que a proximidade física entre estudantes dos dois sexos foi criticada até as últimas décadas do século passado e que a co-educação só foi instituída na escola primária pela reforma Leôncio de Carvalho, em 1879. Alberto Silva, na biografia de Rita Lobato - considerada a primeira médica formada no país - descreve o ritual que o pai da estudante se impunha para que ela seguisse o curso. A fim de poder acompanhar diariamente a filha às aulas, ele mudou-se do Rio Grande do Sul para Salvador. Enquanto a moça assistia o curso em carteira especial, colocada na frente do professor, sem olhar para os lados, o pai, durante três anos seguidos, a esperava na secretaria, "para vê-la acatada e respeitada pelos colegas!" (1954, p. I37).

Em algumas escolas européias a separação entre os alunos do curso de Medicina e as alunas do curso de parteiras era bem delimitada, em prédios separados ou em diferentes períodos do ano (Siebold, 1866, p. 109-35). Isso talvez explique a maior freqüência do curso de Pernambuco em relação aos dois oficiais, já que as alunas tinham aulas no Hospital Paraíso e não no Liceu, ao lado dos demais alunos da escola.

Por outro lado, não se pode esquecer que a necessidade de uma educação para a profissionalização das mulheres, no século XIX, começava apenas a ser reconhecida. Nem mesmo os cursos normais para o sexo feminino, na primeira metade do século, funcionaram regularmente (Barretto, 1981, p. 217, especialmente a Introdução). A educação feminina era pensada no sentido de tornar a mulher uma boa mãe de família, a primeira e a melhor educadora dos filhos e não uma profissional, que fosse buscar o seu sustento fora do lar.

Heleieth Saffioti referindo-se a algumas das razões do fracasso das primeiras tentativas de se implantar o curso normal no Brasil, em meados do século XIX, diz que a escola normal não representava propriamente uma exigência da sociedade brasileira de então, "mas que se constituía meramente num item no conjunto de idéias liberais nascidas em países de economia mais integrada e para aqui transplantadas pela intelligentsia nacional" (I969, p. 198). 0 mesmo tipo de reflexão talvez também possa ser utilizado para o curso para formação de parteiras no Brasil.

Nas primeiras décadas do século XIX, tanto os médicos nacionais quanto os estrangeiros residentes no Brasil criticaram as parteiras práticas do país, culpando-as pela alta taxa de mortalidade materno-infantil. Esse mesmo tipo de crítica vinha sendo feita de forma efetiva, há pelo menos dois séculos, na Europa. Interessados no aumento populacional a partir do século XVIII, vários países europeus criaram cursos para instrução de parteiras, pois acreditavam que esse seria o meio de evitar essas mortes. Ao reformular as antigas academias de Medicina no Brasil, os médicos e os legisladores não teriam tomado como modelo aquilo que era considerado exemplar nos principais países europeus e decidido criar "o nosso curso" de partos para mulheres? 
Jacques Gélis, ao analisar o ensino fornecido às parteiras no século XVIII e início do $X I X$, verifica que em alguns lugares - como na França, na Inglaterra, nos estados do norte da Itália, na Alemanha e em determinados cantões suíços, apesar de enfrentarem dificuldades, os cursos lá criados funcionaram regularmente. Havia uma preocupação efetiva com a taxa de mortalidade das mulheres durante a parturição e das crianças recém-nascidas. Em outros lugares - como nos estados austríacos, na Rússia, na Espanha e no sul da Itália - os cursos foram efêmeros e com resultados limitados, pois foram criados sobretudo pela vontade dos príncipes, sem ter um mínimo de ressonância junto à população (1988, p. 173-94).

Talvez isso tenha sido o que ocorreu no Brasil: os cursos foram criados mais pelo desejo dos médicos de acompanhar o que vinha sendo feito na Europa, do que por uma exigência da sociedade. No século XIX as parteiras práticas eram as preferidas por muitas mulheres, apesar de criticadas por médicos. Com a abertura do país para estrangeiros no início do século XIX, um certo número de parteiras diplomadas aportou nas maiores capitais do país, principalmente na Corte, antes mesmo da criação do curso de parteiras, suprindose assim, rapidamente, a necessidade das famílias abastadas, mais informadas sobre as modas e os costumes europeus.

É possível levantar a hipótese de que a concorrência feita pelas parteiras estrangeiras teria, por sua vez, inibido algumas candidatas aos cursos oferecidos no país. Quanto à questão populacional, ela foi resolvida no Brasil pelo tráfico de escravos, até I 850 e pela imigração de trabalhadores, principalmente brancos, europeus, na segunda metade do XIX.

Um outro dado que me parece relevante, para se entender a questão do reduzido número de alunas nos cursos oficiais é que, no período, o atendimento ao parto e o exercício da Medicina e da cirurgia não eram vistos de forma unânime pela sociedade, como atribuições exclusivas de parteiras, médicos, cirurgiões diplomados. Isto fica evidente nas discussões da classe médica, acima referidas, sobre a formação de médicos, parteiras e farmacêuticos de segunda classe e a licença para o exercício de práticos e curandeiros. A aceitação do exercício da parturição por pessoas sem formação específica pode, ainda, ser percebida nas introduções dos manuais de Medicina doméstica do século XIX, que ensinavam o leitor não profissional (homens e mulheres) a partejar.

O médico Langaard, na introdução do seu manual de partos, afirma que com o livro desejava dar alguns

...conselhos às pessoas que privadas de recursos dos homens da arte viam-se obrigadas, pela força das circunstâncias, a tomar a si tão árdua quanto penosa tarefa, sem terem o conhecimento daquela grande obra que a natureza exerce na ocasião do parto e dos socorros que porventura teriam de prestar àquelas mulheres que infelizes no meio do seu sofrimento acham-se desamparadas, sem terem ao pé de si alguém em que possam confiar; e, antes, se acham rodeadas de prejuízos e erros, que aumentam o perigo e põem em risco a vida da mãe e filho ou os sacrificam à morte certa e prematura. (I862, p. I, II) 
A aceitação da participação no parto por pessoas sem formação específica fica também evidente no triste episódio ocorrido por ocasião do primeiro parto da Princesa Isabel. Como a criança estava mal posicionada e não nascia, a parteira presente relatou que até D. Pedro II chegou a manejar o fórceps, depois de infrutíferas aplicações feitas pelos três médicos responsáveis pela parturição! (Magalhães, 1922, p. 152). Apesar da compreensível ansiedade do soberano diante do nascimento daquele que seria herdeiro do trono, do desespero do pai com o sofrimento da filha, e do fato de ele, D. Pedro, ser o Imperador, esta atitude dificilmente seria imitada ou legitimada na atualidade. No presente, os médicos certamente receberiam severas críticas e seriam punidos pelo Conselho de Medicina por terem permitido a interferência de uma pessoa não autorizada na operação, mesmo que se tratasse da autoridade máxima da nação.

Por que então fazer um curso de partos, tendo muitas vezes de mudar de província, num período em que os meios de transportes eram precários, se era possível aprender o ofício em um manual? E mais: por que uma mulher iria freqüentar dois anos de curso, se ausentar do lar, abandonar as importantíssimas atividades rotineiras da casa, onde era confeccionada a maioria dos produtos de consumo, se as autoridades faziam vistas grossas, não puniam as infratoras que partejavam sem diploma?

Dr. Carrão, num artigo intitulado "Algumas considerações a cerca da importância e necessidade de parteiro durante o trabalho de parto", depois de reclamar da falta de habilidade das parteiras no Brasil diz:

Nem se diga que o país não oferece instrução. Existe na Escola de Medicina um curso completo de partos, ao qual podem concorrer as mulheres que quiserem se dedicar à arte de partejar, donde podem sair com a instrução precisa, e legalmente autorizadas para o exercício do seu magistério. Mas como no nosso país não há política médica, e as autoridades não cumprem os seus deveres, o charlatanismo se acha por tal ponto acoroçoado, que qualquer indivíduo pode curar, partejar, e ter botica sem apresentar diploma: disto resulta que ninguém se quer entregar ao estudo, expor-se às provas, e fazer despesas, quando longe destes sacrificios podem obter as mesmas vantagens. E para que um diploma da Faculdade de Medicina, quando as denominações de parteira da Maternidade tal, discípula do Dr. f. são títulos suficientes para merecer a confiança do público, e a proteção das autoridades. (1848, p.8)

A possibilidade de partejar sem diploma pode ser verificada ainda no final do século XIX. Em I 885, a parteira Ana Maria de Oliveira Godoy colocou um anúncio no Almanaque Laemmert (em 1885) oferecendo nestes termos seus serviços: "não é parteira de primeira classe, nem possui diploma porém tem 24 anos de serviço prático em cuidar de suas amigas e comadres, sem exigir pagamento" (p.795).

Para concluir, gostaria de levantar uma última questão sobre a razão do pequeno número de alunas e a relação que isso poderia ter com a mudança do perfil social, sexual e 
étnico dos profissionais encarregados da parturição, sobretudo a partir da segunda metade do século XIX, nos centros urbanos mais desenvolvidos.

Conforme se viu no decorrer deste artigo, seja nos projetos de reforma (mesmo naqueles referentes à formação de parteiras de segunda classe), como nas críticas feitas ao curso de partos, as medidas propostas foram sempre tomadas visando se restringir, cada vez mais, o acesso ao curso a um perfil de mulher diferente daquele que se atribuía às parteiras tradicionais. Enquanto as mulheres que exerciam o ofício eram consideradas em geral como sendo provenientes das camadas mais baixas da sociedade, escravas, negras e mulatas livres, de comportamento moral duvidoso, velhas, supersticiosas, analfabetas, exigia-se que as alunas do curso de partos fossem jovens, que tivessem uma moralidade comprovada pelo Juiz de Paz, estivessem sob a supervisão do pai ou do marido e tivessem um pecúlio suficiente para pagar a matrícula, que fossem alfabetizadas - que soubessem inclusive francês - como também Aritmética, conhecessem Álgebra e Geometria e, depois da década de 80, Física, Química e História Natural.

Será que as exigências para o ingresso no curso de parteiras não poderiam estar relacionadas com o desejo dos reformadores do ensino médico não só de valorizar socialmente a profissão, já que a parturição era um campo profissional que começava também a ser atraente para os médicos, como também restringir o acesso das mulheres ao curso, reduzindo assim o número de parteiras diplomadas? A disputa pela clínica particular no final do século $X I X$ e início do $X X$, pelo menos na cidade do Rio de Janeiro, parece ter sido muito acirrada. Fernando Magalhães chega mesmo a dizer que foi censurado por colegas pelo fato de divulgar tanto a especialidade. E conclui: "É bem possível que a idéia de monopolizar a clínica restringisse muito o ensino da obstetrícia" (1922, p. |32).

\section{REFERÊNCIAS BIBLIOGRÁFICAS}

Fundos de arquivos citados

Arquivo da Cidade do Rio de Janeiro - AGCRJ

Cód. 8-3-7 - Junta de Higiene

Cód. 44-2-27 - Hospitais e Casa de Saúde

Cód. 44-4-27 - Hospitais e Casa de Saúde

Cód. 44- I- 48 - Hospitais e Casa de Saúde

Cód. 46-2- 39 - Hospitais e Casa de Saúde

Cód. 47-1 -48 - Hospitais e Casas de Saúde

Cód. 47- I-49 - Hospitais e Casa de Saúde 
Arquivo Nacional - AN

Cód. I E3 26 - Ministério do Interior - Educação

Cód. 807, vol. 4 ( I 832) - Le Masson - Sobre a necessidade de um hospital para ensinar Obstetrícia

Cx. IS4 23, doc. 49 e 72 - Ministério do Interior - Saúde

Obras impressas citadas

ABREU, F.B. Memória histórica da Faculdade de Medicina do Rio de Janeiro do ano de 1863 apresentada à respectiva Congregação. Rio de Janeiro, scp, s.d.

ACADEMIA IMPERIAL DE MEDICINA. Relatório dos trabalhos. Anais Brasiliense de Medicina, v.23, n.8, p.289, jan. 1872; v.23, n.9, p.334, fev. 1872.

ALMANAQUE LAEMMERT de 1885.

ALMEIDA, J.R.P. História da Instrução Pública no Brasil( I 500- | 889). Brasília, INEP; São Paulo: PUC, 1989.

AMERICANO, D.M.D. Memória sobre o estado atual das instituições médicas de França, Prússia e Grã-Bretanha. Rio de Janeiro: Tip.Nacional, 1845.

ARAGÃO, G.M.A. A Medicina e sua evolução na Bahia. Bahia, 1923.

BARBOSA, R. Obras Completas. v.9, tomo I. Rio de Janeiro: Ministério de Educação e Saúde, 1942. Reforma do ensino secundário e superior.

BARRETTO, E.S.S. Bibliografia anotada da mulher brasileira: educação. São Paulo: Brasiliense; Fundação Carlos Chagas, 1981. Introdução.

BERTHOU, E. Compêndio das doenças e outras indisposições das mulheres, para servir de guia às parteiras na Arte de Partos, precedido de uma dissertação sobre o tato... Rio de Janeiro: Tip. Imperial de Émile Seignot-Plancher, 1830.

BRASIL. Coleção de Leis e Decretos do Império. Aviso n. 160, 4/4/I 86 I.

. Decreto n. 1387, 28/4//854.

. Decreto n. 1852, 1\%/8/1868.

. Decreto n. $7247,5 / 4 / 1879$.

. Decreto n. 931।, 25/1 1/1884.

. Lei de 3/10/1832.

BRENES, A.C. Nascimento e declínio da Escola de Parteiras francesas: | 802- | 877. Revista Médica de Minas Gerais, v.9, n. I, p.39-45, jan.-mar. 1999. 
. Um Olhar brasileiro sobre o caso de Paris: o conflito entre parteiras-parteiros e seus desdobramentos no Rio de Janeiro no século XIX. Rio de Janeiro, 1996. Tese (Dout.) História Social, Depto. de História, Universidade Federal Fluminense.

CARRÃO. Algumas considerações acerca da importância e necessidade de parteiro durante o trabalho de parto. Arquivo Médico Brasileiro, n.9, p.8, 1848.

COSTA, F.A.P. Dicionário biográfico de pernambucanos célebres. Recife: Fundação de Cultura da Cidade de Recife, 1982.

COSTA, S. Criação de médicos e farmacêuticos e parteiras de segunda classe. Gazeta Médica do Rio de Janeiro, n.21, p.248, 0 I nov. 1863; n.22), 15 nov. 1863.

CUNHA, M.C.C. Fala com que o Exmo. Dr. M.C. Carneiro da Cunha abriu a sessão da Assembléia Legislativa de Pernambuco 2/3//877. Pernambuco: Tip. de M. Figueiroa de Faria, 1877.

DIAS, A.G. Instrução Pública em diversas províncias do Norte (Relatório Gonçalves Dias), In: ALMEIDA, J.R.P. História da instrução pública no Brasil( (1500-1 889). São Paulo: EDUC; Brasilia: INEP, 1989.

DUROCHER, M.J.M. Considerações sobre a Clínica Obstétrica. Anais da Academia de Medicina, v.2, n.3, p.240-342, jan.-mar. 1887.

. Deve ou não haver parteiras? Anais Brasiliense de Medicina, v.22, n.5, p.256-7I, out. 1870; v.22, n.9, p.289-302, fev. I87I; v.22, n. 10, p.329-36, mar. I87I.

EDLER, F.C. As Reformas do ensino médico e a profissionalização da Medicina na Corte do Rio de Janeiro. São Paulo, 1992. Dissert. (Mestr.) FFLCH/USP.

FIGUEIREDO, J.B.C. Relatório que a Assembléia Legislativa apresentou no dia da abertura da sessão ordinária de 1855, o Presidente da Província. Recife: Tip. M. F. Faria, 1855.

GAMA, C. Relatório que o Presidente de Provincia Chichorro da Gama apresentou à Assembléia Legislativa de Pernambuco, em 1847. Recife: Tip. Faria, 1847.

GÉLIS, J. Sage-femme ou le médecin: une nouvelle concepcion de la vie. Paris: Fayard, 1988.

JORGE, D. R. Evolução da legislação federal do ensino e do exercício profissional da obstetriz (parteira) no Brasil. Rio de Janeiro, 1972. Tese (Livre-Docência) Escola de Enfermagem Anna Nery, UFRJ.

JORNAL DO COMÉRCIO. Rio de Janeiro, II maio 1832.

LACERDA, M.C.C. Fala com que o Exmo. Dr. A. B. C. de Lacerda abriu a sessão da Assembléia Legislativa de Pernambuco 19//2//878. Pernambuco: Tip. de M. Figueiroa de Faria, 1879. 
LANGAARD, T.J.L. Arte obstétrica ou tratado completo dos partos. Rio de Janeiro: Laemmert, 1862.

MAGALHÃES, F. A Obstetrícia no Brasil. Rio de Janeiro: Ribeiro Leite, 1922.

MAIA, C.M. Breves apontamentos do ensino médico em Paris: primeiro relatório. Paris: Tip. A. Parent, 1876.

MEIRELES, J.C.S. Observações do projeto do Sr. Deputado Lino Coutinho acerca das Escolas de Medicina. Rio de Janeiro: Tip. do Diário, 1828.

MOACYR, P. Instrução no Império. São Paulo: Ed. Nacional, 1936-38.

MORAIS, J.P.C. Fala com que o Exmo. Sr. Conselheiro João Pedro Carvalho de Morais abriu a sessão da Assembléia Legislativa de Pernambuco /\%/3//876. Pernambuco: Tip. de M. Figueiroa de Faria, 1876

MOTT, M.L.B. Parto, parteiras e parturientes no século XIX: Mme. Durocher e sua época. 1998. Tese (Dout.) História Social, Depto. de História, USP.

PARECER apresentado a 19 de outubro próximo passado pela Comissão nomeada em 15 do mesmo mês por esta Faculdade sobre a proposta do Governo Imperial respectiva à criação de médicos, farmacêuticos e parteiros de $2^{a}$ classe. Rio de Janeiro: Tip. Nacional, 1863.

PERNAMBUCO. Instrução Presidente de Província. 30/3/184I. . Legislação Provincial. Lei n. 87 de 6/5/1840.

. Legislação Provincial. Regulamento do Serviço Médico da Santa Casa de 29/3/I 875. . Legislação Provincial. Regulamento Provincial de 27/7// 855.

ROCHA, L.A. Curso de parteiras em Pernambuco. In: ROCHA, L. A. Velhos médicos, velha medicina. Recife: Arquivo Público, 1953.

SAFIOTTI, H. A Mulher na sociedade de classes. São Paulo: Quatro Artes, 1969.

SANTOS FILHO, L. História Geral da Medicina Brasileira. São Paulo: Hucitec; EDUSP, I 99I.

SIEBOLD, Ed.J. von. Lettres obstétricales. Paris: J. B. Baillière, 1866.

SILVA, A. A Primeira médica no Brasil. Rio de Janeiro: Pongetti, 1954.

STOCK-MORTON, P. Control and limitation of midwives in Modern France. Journal of Women 's History, v.8, n. I , p.60-93, spring 1996.

XAVIER, F.J. Parecer que a Faculdade de Medicina do Rio de Janeiro apresentou ao Sr. Dr. (...) sobre a criação de um Hospício Maternidade na Corte. Arquivo Médico Brasileiro, p.257-62, 1845. 